\section{INTRODUCCIÓN A LA \\ DESCOLONIZACIÓN DE LAS CIENCIAS SOCIALES Y LA EDUCACIÓN: \\ Elementos para la construcción de pensamiento propio}

\section{Gerardo León Guerrero Vinueza}

\begin{abstract}
Este libro es una publicación del Doctorado en Ciencias de la Educación de la Universidad de Nariño -RUDECOLOMBIA y está centrado principalmente en mostrar la importancia que tiene la descolonización del saber y del poder, para construir un pensamiento propio que distinga e identifique al americano, e insiste en que es momento de construir nuestras propias miradas $\mathrm{y}$ visiones sin desconocer la historia y trayectoria que ha tenido la cultura occidental en nuestra América, esto a raíz de que los modelos ideológicos, pedagógicos, económicos y concepciones de las ciencias sociales que moldean a los latinoamericanos siguen siendo de origen occidental.
\end{abstract}

Se menciona la real importancia que se les debe otorgar a las ciencias sociales, dado que no han sido reconocidas como tal, pues son estas las que estudian a las personas, se encargan de comprender, interpretar, analizar y reflexionar sobre los comportamientos, actitudes y relaciones sociales que se establecen dentro de la humanidad, además en ellas se expresa la forma de vivir, de pensar y de ser de la sociedad.

Por otra parte, el autor indica que el aporte que ha hecho el cientificismo para bien o para mal ha sido rotundo en función de la humanidad, en cuanto ha mejorado las condiciones de vida, ha inventado cada día más comodidades para la sociedad, pero no ha sido tan favorable para la naturaleza, pues fue a raíz de la revolución del cientificisismo que el ser humano se autoproclamó dueño para disponer a su capricho la naturaleza y sus recursos, aspecto que en esta etapa de la historia no está a nuestro favor, esto digo por lo indiscutible del momento y la situación, todo lo que abarca la problemática ambiental, de la cual es absolutamente responsable el ser humano, consecuencia de la concepción europea donde se concibe al hombre como dueño y señor de lo que a su alrededor yace, este pensamiento también colonizó al americano, llevándolo al punto en donde hoy nos encontramos, sin tener oportunidad de deshacer el daño ambiental que está profundamente marcado, es preciso mencionar en esta parte, que para la cultura andina el hecho de explotar a la naturaleza no estaría en negociación por la misma concepción de naturaleza 
que tenían y tienen los indígenas que quedan sin colonizar, concebida por ellos la naturaleza como dadora de vida, no como bodega de recursos interminables.

Se resalta los diferentes juicios que se suscitan frente a la veracidad de las ciencias naturales y las ciencias sociales, las primeras concebidas como objetivas, experimentales, probables y las segundas consideradas por muchos empiristas como especulativas, a lo mejor por que el sujeto de estudio es la misma sociedad, no tanto objetiva, no tanto probable.

En un capitulo seguido, el autor menciona varios aspectos que el Eurocentrismo logró esbozar en América Latina después del "descubrimiento", es ejemplo de ello el decir que América comenzó a existir para el mundo después de haber sido descubierta, por tal razón los europeos establecieron que era un continente sin cultura, sin intelecto, sin identidad, inferior ante los demás y por ello decidieron imponerse con sus creencias, sus reglas, fue así como la humanidad Americana segada y sorprendida por todo lo que acarreó la visita de los europeos se vio manipulada hasta adoptar todo lo impuesto por los visitantes; por ello el autor nos invita a reflexionar críticamente sobre los acontecimientos pasados, a no olvidar la historia que nos marcó y a tratar de cambiarla desde nuestro ser y saber latino, reconociéndonos como Americanos y Americanas, recuperando nuestra cultura, destacando y desenterrando todo ese bagaje de conocimiento e ideología que un día perdimos a causa de ser descubiertos, pues América y su gente tiene su propia historia, como continente existió y ha existido con o sin descubrimiento.

Por otro lado, un aspecto que se resalta es que a pesar de la importancia merecida que se les debería otorgar a las ciencias sociales en estos tiempos por la contribución que hacen al conocimiento, no hay que olvidar que estas ciencias también han migrado hasta América desde Europa, es así como la antropología, sociología, Historia, la economía, etc., muestran la realidad desde las concepciones de los europeos, realidad que se sigue reproduciendo hasta la actualidad en América; y para mitigar este proceso es necesario que no se siga trasmitiendo lo mismo de siempre, si no que por medio de la educación se haga el esfuerzo necesario para empezar a recopilar y mostrar lo Americano, lo latino, el pensamiento propio, el cual tiene absoluto valor por ser nuestro y no ajeno.

De ahí, subyace la necesidad de reevaluar la epistemología de las ciencias sociales que nos han mostrado y sobre las cuales nos han educado, dado que en ellas, se sigue replicando cuáles países son modelos a seguir y cuáles no desde el punto de vista europeo; es aquí cuando el autor habla de la urgente descolonización de las ciencias sociales y la educación, dado que son las principales bases que seguirán colonizando o por fin empezarán a descolonizar a nuestra América y lograr que sea reconocida como el continente que recuperó su identidad y construyó pensamiento propio y no por continuar hasta el final con una imposición extranjera.

Diana Maribel Cuesta Caicedo

Miembro activo del Grupo de Investigación: Historia, Educación y Desarrollo - HISED,

Universidad de Nariño 